\title{
Broad Casts Measurement
}

National Cancer Institute

\section{Source}

National Cancer Institute. Broad Casts Measurement. NCI Thesaurus. Code C96588.

The determination of the amount of urinary broad (waxy) casts present in a sample. 